\title{
Method for quantifying expression of functionally active topoisomerase II in patients with leukaemia
}

\author{
A R Cattan, D Levett, E A Douglas, P G Middleton, P R A Taylor
}

\begin{abstract}
Aims-To produce a method to measure and quantify enzymatically active topoisomerase II in normal and neoplastic human cells.

Methods-A crude cell lysate from density separated mononuclear cells from either peripherial blood or bone marrow was prepared as a source of topoisomerases. Using the lysate, minicircles from the Crithedia kinetoplast DNA complex were decatenated before being separated by agarose gel electrophoresis and visualised using ethidium bromide/ultraviolet fluorescence.

Results-Cell number, sample volume and drug inhibition concentration required to produce reliable and reproducible assay conditions were established. Intra- and interassay standards were included which permitted the quantification of active topoisomerase $\mathrm{II}$ in matched peripheral blood, bone marrow, presentation, and relapse samples from patients with acute lymphoblastic leukaemia. Active topoisomerase II has been converted to a unit scale which has been used to compare topoisomerase II activities in cells from patients with normal blood and bone marrow samples.

Conclusions-There was no change in topoisomerase II activities between samples taken at presentation and those taken during a recurrence. However, topoisomerase II activity in leukaemic blast populations was increased compared with topoisomerase II activity in normal cells. (F Clin Pathol 1996;49:848-852)
\end{abstract}

Keywords: drug resistance, topoisomerases, leukaemia.

At presentation, most acute leukaemias show some response to treatment; however, with time most adult patients succumb to their disease due to relapse. Following relapse, treatment protocols become less effective and drug concentrations are escalated with the addition of other chemotherapeutic agents. This phenomenon of failing response to therapy with increased tumour load is often referred to collectively as the development of drug resistance. There are many in vitro and in vivo models used to describe the development of drug resistance, including the multidrug resistance phenotype or MDR, ${ }^{1}$ drug detoxification, ${ }^{2}$ changes in both the level and structure of the drug target, ${ }^{3}$ and changes in DNA repair mechanisms. ${ }^{45}$ All of these mechanisms may work alone or in concert to produce the phenotype in vivo of the eventual failure of response to treatment seen in patients with leukaemia. ${ }^{6}$

The topoisomerases are a ubiquitous family of enzymes seen in bacteria (DNA gyrases) and in eukaryote organisms where two major forms exist: topoisomerase I which catalyse single strand DNA breaks and ligations; and topoisomerase II which catalyse the cleavage and ligation of double strand DNA breaks. These enzymes are believed to play important roles in DNA replication, repair and in gene transcription (for review see ${ }^{78}$ ). In mammalian cells there are two forms ( $\alpha$ and $\beta$ ) of topoisomerase II. ${ }^{9}$ Little is still known about their explicit roles although there are reported associations with the cell cycle ${ }^{10}$ and changes in expression of the two forms in cell lines under cytotoxic drug selection. ${ }^{11}$

A variety of drugs used in the treatment of leukaemia, including the anthracyclines (daunorubicin, idarubicin), epipodophyllotoxins (VP-16) and anthraquinone (mitoxantrone), are known to target topoisomerase II, and may be partly responsible for the antineoplastic effects found. Attempts to measure activities of topoisomerase II and changes in their properties in mammalian cellular preparations have been largely restricted to cell lines. ${ }^{12-14}$ Topoisomerase II activities in clinical leukaemic samples have been reported using slot blots to detect specific $\mathrm{mRNAs} \mathrm{s}^{15}{ }^{16}$ and by western blotting to detect protein and determine protein concentrations. ${ }^{16}{ }^{17}$ As topoisomerase II expression has been shown to be decreased in cell lines exposed to cytotoxic agents, ${ }^{17}{ }^{18}$ several groups have attempted to show a similar correlation in clinical specimens with the hope of relating this to clinical outcome. Although it has been reported that topoisomerase II $\widetilde{N}$ expression changes during treatment, most investigations have been unable to correlate this expression with remission status. ${ }^{15-17}$ Ellis et $a l^{19}$ have described a filter based assay to quantify biologically active topoisomerase II in a cell line with the intention of using this method in an attempt to predict the development of drug resistance to the topoisomerases.

Quantification of topoisomerase II by either measurement of mRNA or specific protein and the use of this to correlate topoisomerase II activity with drug resistance phenotype does not take into account that the protein may be non-functional. It is known that phosphorylation status affects topoisomerase II function and that this may alter the antineoplastic effect of the drugs in question. ${ }^{8}$ In an attempt to address this problem, we have developed an assay to measure biologically active topoisomerase II in leukaemic samples. We report 
Table 1 Patient details

\begin{tabular}{|c|c|c|c|c|c|c|}
\hline $\begin{array}{l}\text { Patient } \\
\text { number }\end{array}$ & Age & Sex & $\begin{array}{l}\text { Diagnosis } \\
\text { phenotype }\end{array}$ & $\begin{array}{l}\text { Presenting } \\
W B C \times \\
10^{9} / l\end{array}$ & $\begin{array}{l}\text { Remission status } \\
\text { achieved }\end{array}$ & $\begin{array}{l}\text { Anti-leukaemic chemotherapy given } \\
\text { prior to sample }\end{array}$ \\
\hline Control & 73 & $M$ & B-CLL & & & $\begin{array}{l}\text { Chlorambucil }(832 \mathrm{mg}) \text {, } \\
\text { prednisolone }(520 \mathrm{mg})\end{array}$ \\
\hline ALL1 & 23 & $\mathrm{~F}$ & $\begin{array}{l}\text { Calla+ } \\
\text { ALL }\end{array}$ & 190 & $\begin{array}{l}\text { Complete } \\
\text { remission }\end{array}$ & $\begin{array}{l}\text { Induction therapy }+ \text { intensive } \\
\text { therapy }+ \text { consolidation }+ \text { allograft }\end{array}$ \\
\hline ALL2 & 48 & $\mathbf{M}$ & T-ALL & 357 & $\begin{array}{l}\text { Complete } \\
\text { remission }\end{array}$ & $\begin{array}{l}\text { Induction therapy }+ \text { intensive } \\
\text { therapy }+ \text { consolidation }+ \text { allograft }\end{array}$ \\
\hline ALL3 & 39 & $\mathbf{M}$ & preB-ALL & 63.3 & $\begin{array}{l}\text { Complete } \\
\text { remission }\end{array}$ & $\begin{array}{l}\text { Induction therapy }+ \text { intensive } \\
\text { therapy }+ \text { consolidation }+ \text { allograft }\end{array}$ \\
\hline ALL4 & 16 & $\mathbf{M}$ & $\begin{array}{l}\text { Callat } \\
\text { ALL }\end{array}$ & 44.2 & No remission & $\begin{array}{l}\text { Induction therapy }+ \text { intensive } \\
\text { therapy }\end{array}$ \\
\hline ALL5 & 62 & $\mathrm{~F}$ & B-ALL & 19.4 & No remission & None \\
\hline ALL6 & 16 & $\mathbf{M}$ & $\begin{array}{l}\text { Null } \\
\text { ALL }\end{array}$ & 44.8 & No remission & None \\
\hline ALL7 & 21 & $\mathbf{M}$ & $\begin{array}{l}\text { Calla+ } \\
\text { ALL }\end{array}$ & 13.7 & No remission & None \\
\hline ALL8 & 47 & $\mathrm{~F}$ & $\begin{array}{l}\text { Null } \\
\text { ALL }\end{array}$ & 43.4 & $\begin{array}{l}\text { Complete } \\
\text { remission }\end{array}$ & None \\
\hline ALL9 * & 42 & $\mathrm{~F}$ & preB-ALL & 63.7 & $\begin{array}{l}\text { Complete } \\
\text { remission }\end{array}$ & None \\
\hline
\end{tabular}

^Leukaemia secondary to treatment for Hodgkin's disease; WBC $=$ white blood cell.

the characterisation of this assay and the expression of functional topoisomerase II in leukaemic blasts taken from patients with acute lymphoblastic leukaemia (ALL).

\section{Methods}

PATIENTS

The diagnosis of leukaemia was made by a consultant haematologist using Romanovsky stained blood and marrow smears and was confirmed by appropriate cytochemical staining and immunophenotyping of the leukaemic blasts. Details of the patients at presentation are shown in table 1 . All cases were of de novo leukaemia except for patient ALL9 where the leukaemia was considered secondary to previous chemotherapy for Hodgkin's disease. All patients received initial chemotherapy according to the NEALL III Protocol. ${ }^{20}$ Remission induction therapy was with vincristine, prednisolone, adriamycin, and cytosine. If complete remission (defined as $<5 \%$ blasts in an adequately cellular marrow) was not achieved by seven weeks, then further intensive treatment with high dose cytosine and mitoxantrone was given. Four patients did not achieve complete remission. Two patients had recognised adverse factors (ALL6, Ph chromosome positive; ALL7, B-ALL) and a third (ALL8) evolved to acute myeloid leukaemia after five weeks on treatment. Consolidation treatment was with vincristine, steroids, cytosine, asparaginase, methotrexate, and 6-thioguanine. Patients for autograft and allograft were conditioned with high dose melphalan and total body irradiation.

PREPARATION OF CELL LYSATE

Mononuclear cells were separated from peripheral blood or bone marrow using Lymphoprep (Nycomed) and kept in the liquid nitogen vapour phase. Pooled cells $\left(5 \times 10^{7}\right)$ were washed once with phosphate buffered saline (PBS) containing $10 \mathrm{mM}$ EDTA and the lysate prepared according to the method of Melendy and Ray. ${ }^{21}$ The harvested supernatant which formed the crude topoisomerase II lysate was used immediately and also stored diluted 1 in 1 with glycerol at $-80^{\circ} \mathrm{C}$.
PREPARATION OF CRITHEDIA DNA

Crithedia fasciculata (a gift of Dr I Hickson, Oxford) was grown in brain heart infusion medium (Difco) containing $10 \mu \mathrm{g} / \mathrm{ml}$ hemin, $100 \mu \mathrm{g} / \mathrm{ml}$ penicillin, $0.125 \mu \mathrm{g} / \mathrm{ml}$ streptomycin at $28^{\circ} \mathrm{C}$ to $1-5 \times 10^{7} / \mathrm{ml}$. DNA was prepared from the harvested protozoa $\left(2 \times 10^{11}\right)$ using standard lysis and chloroform/alcohol extraction methods. The mixture of genomic and kinetoplast DNA was treated with RNase A (bovine pancreas; Sigma, Poole, Dorset, UK) for 60 minutes at $37^{\circ} \mathrm{C}(50 \mu \mathrm{g} / \mathrm{ml}$ final concentration) and then mixed with molecular weight marker (5:3 ratio Hind III digested bacteriophage $\lambda$ markers; Integra Biosciences) to form the target DNA for the topoisomerase II assay.

ASSAY OF TOPOISOMERASE II ACTIVITY

The assay is an adaption of the assay of Davies et al. ${ }^{22}$ Briefly, $5 \mu$ reaction buffer $(50 \mathrm{mM}$ Tris (pH 7.9), $120 \mathrm{mM} \mathrm{KCl}, 10 \mathrm{mM} \mathrm{MgCl} 2,0.5$ $\mathrm{mM}$ EDTA, $30 \mu \mathrm{g} / \mathrm{ml}$ bovine serum albumin, 5 $\mathrm{mM}$ DTT, $5 \mathrm{mM}$ ATP), $5 \mu \mathrm{l}$ adriamycin (380 $\mathrm{ng} / \mathrm{ml}$ in water), $24.5 \mu \mathrm{l}$ water, $7.5 \mu \mathrm{l}$ cell lysate, and $8 \mu \mathrm{l}$ Crithedia/ $\lambda$ DNA phage were mixed in a microcentrifuge tube, incubated at $30^{\circ} \mathrm{C}$ for 30 minutes and the reaction stopped by the addition of $12.5 \mu \mathrm{l}$ stop solution ( $5 \% \mathrm{w} / \mathrm{v}$ SDS, $30 \%$ glycerol, $2.5 \mu \mathrm{g}$ bromophenol blue).

PROTEIN ESTIMATION

Protein content in lysates was measured according to the method of Bradford, ${ }^{23}$ adapted for use on a 96 well plate reader (Multiskan MCC 340).

GEL ELECTROPHORESIS AND DENSITOMETRIC

MEASUREMENTS

Assay samples were run for 16 hours in $0.8 \%$ (w/v) agarose using standard DNA electrophoresis conditions and bands visualised with ethidium bromide. Following electrophoresis the resulting separations of DNA molecules were visualised by ultraviolet illumination of the DNA-ethidium complexes (302 nm transillumination) and the image stored electronically for further analysis (UVP 2000, Ultaviolet Products Ltd). The units of topoisomerase II were calculated by adjusting the ratio of the total area of topoisomerase II to $\lambda$ marker bands to those produced by an aliquoted control lysate in that particular test and corrected to the relevant point on a standard curve (fig 1). This correction was made for each patient sample such that the units of topoisomerase II were calculated using the formula below:

Units/ml (topoisomerase II) $=$ Lysate $\times$ Correction Factor Control Lysate $\times$ Correction Factor

These units were expressed as units/mg protein and as units $/ 1 \times 10^{7}$ cells.

\section{Results}

TITRATION OF CONTROL LYSATE CONCENTRATION After density separation, a topoisomerase II lysate was prepared from cells from a patient with chronic lymphocytic leukaemia (CLL) and aliquots were frozen at $-80^{\circ} \mathrm{C}$ in $50 \%$ glycerol. These aliquots have been stable for 12 months without any appreciable loss of activity 

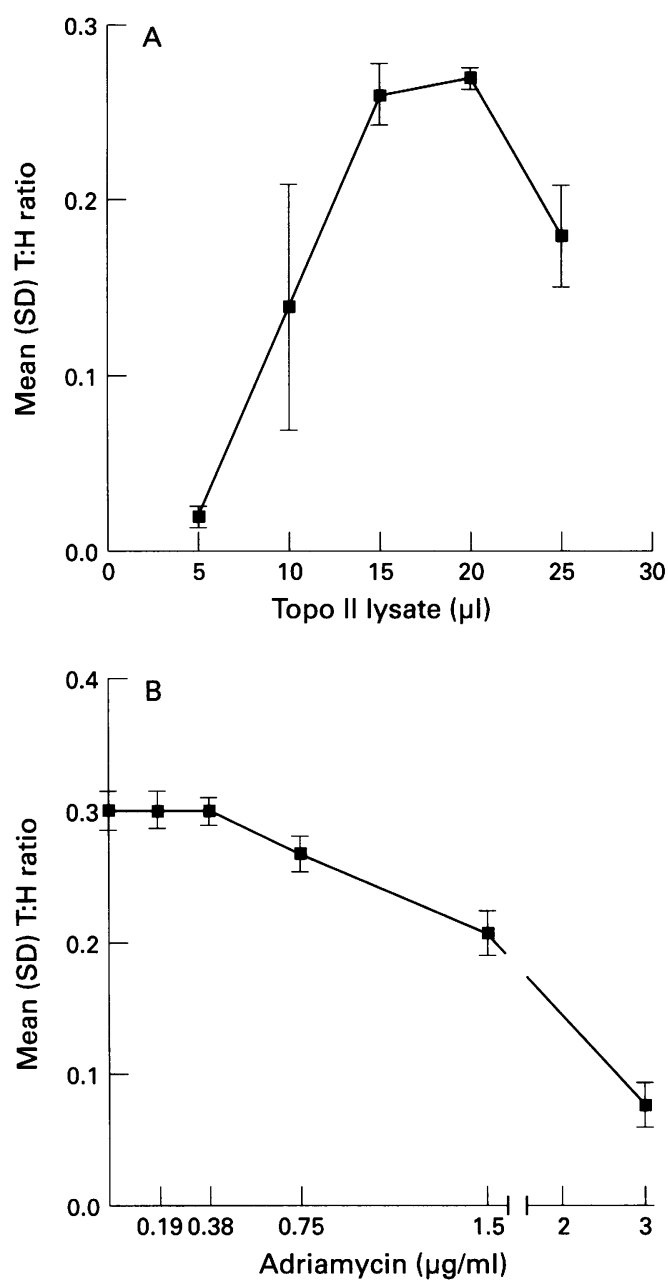

Figure 1 (A) Titration of cell lysate volume for the internal control and standard topoisomerase II assay. The $y$-axis shows the ratio of all topoisomerase II bands to Hind III digests of $\lambda$ phage densometric areas and the $x$-axis cell lysate volumes. Points expressed are means for five separate experiments with bars showing standard deviation. (B) The $y$-axis shows an adriamycin inhibition curve of decatenation/catenation of kinetoplast DNA using the CLL standard cell lysate. Points expressed are means for 10 separate experiments with bars showing standard deviation.

(results not shown). Figure 1A shows a standard curve ( \pm standard error) compiled from five separate experiments made in triplicate. From this curve the sample and internal standard volumes were fixed at $15 \mu \mathrm{l}$. The ratio of the total area for the topoisomerase II bands to the total area for the Hind III digested $\lambda$ phage allowed us to correct for variations in sample gel tract loading as densitometry could not be performed on the added kinetoplast as it was too large to enter the gel. The Crithedia genomic DNA presented too diffuse a band to give dependable densitometry.

DRUG INHIBITION PHENOTYPE IN THE

TOPOISOMERASE II ASSAY

To determine the sensitivity of the assay to various chemotherapeutic drugs, assays were done with various concentrations of drugs known to inhibit topoisomerase II (adriamycin, elliptocine, etoposide, $\mathrm{N}$-ethylmalemide, novobiocin). Table 2 shows the concentrations of various drugs required to inhibit by $50 \%$ the decatenation and catenation of kinetoplast DNA using the internal standard (CLL). This decatenation/catenation reaction is dependent on the presence of ATP and $\mathrm{Mg}^{2+}$ ions and independent of the presence of Crithedia genomic DNA (fig 2). As similar results were found when purified kinetoplasts were used, all $\Omega$ experiments reported were using the mixture $\bar{\Xi}$ of Crithedia genomic and kinetoplast DNA (table 2). When genomic DNA only was used, none of the characteristic forms of kinetoplast minicircles were found (results not shown).

TITRATION OF ADRIAMYCIN CONCENTRATION Using adriamycin, one of the drugs reported to $\overline{\frac{D}{}}$ inhibit topoisomerase II, we constructed an $\stackrel{\mathbb{D}}{\circ}$ inhibition curve for the decatenation/catenation of kinetoplast DNA (fig 1B). The 50\% inhibition of release of kinetoplast minicircles? occurred at $38 \mathrm{ng} / \mathrm{ml}(72 \mathrm{nM})$ in our assay sys- $\vec{\omega}$ tem. Adriamycin was subsequently added to each topoisomerase II assay at a final concen- $\frac{\overrightarrow{0}}{0}$ tration of $38 \mathrm{ng} / \mathrm{ml}$. This amount was found $\overrightarrow{0}$ empirically to give a smaller standard deviation in the decatenation/catenation ability of the internal control and test sample triplicates $\stackrel{\infty}{\infty}$ (data not shown). At this concentration, small 윽 changes in topoisomerase II activities result in large changes in optical density and as a consequence in topoisomerase II expressed as our $\frac{0}{0}$ defined units. With each experiment, an $\underset{\mathbb{D}}{ }$ aliquot of the CLL control topoisomerase II lysate was included with this fixed concentration of adriamycin. We adjusted the value found with the internal control to that expected from the standard curve, to control for interassay variability and to provide the correction factor in order to compare different patient samples.

\section{TOPOISOMERASE II ACTIVITIES IN ACUTE}

LYMPHOBLASTIC LEUKAEMIA CELLS

Cells were isolated using differential density centrifugation from peripheral blood or bone $\frac{?}{0}$ marrow of patients with ALL. In 4 cases matched pairs of peripheral blood and bone marrow or in a further four cases presentation $\delta$ and relapse samples were available for com- $₹$ parison of their topoisomerase II activities (fig 옥 2 ). The cell source, the percentage of leukae- $\rightarrow$ mic blasts in the sample, the presentation/ remission status of the patient at the time of $\mathrm{N}$ sampling and the number of topoisomerase $\mathrm{II}_{\mathrm{N}} \mathrm{N}$ units both as per $\mathrm{mg}$ of cellular protein and per $N$ $1 \times 10^{7}$ cells are shown in table 3 ; fig 3 . The mean and standard deviation for topoisomerase II units for 10 peripheral blood mononuclear cell samples and for eight bone marrow mononuclear cell samples from normal sub- 0 jects are also shown. There was no consistent ${ }_{0}^{\circ}$

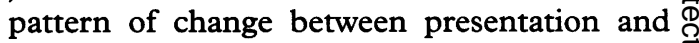
relapse samples. The protein concentrations $\mathbb{Q}$ vary with both increases (ALL3) and decreases

Table 2 Concentrations of drugs required to inhibit decatenation/catenation of kinetoplast DNA by $50 \%$

\begin{tabular}{ll}
\hline Drug & IC50 $(\mu \mathrm{g} / \mathrm{ml})$ \\
\hline Adriamycin & 1.0 \\
Elliptocine & 12.5 \\
Etoposide & $>1000$ \\
N-ethylmalemide & $>500$ \\
Novobiocin & $>500$ \\
\hline
\end{tabular}


Table 3 Topoisomerase II and protein concentrations in patient and normal tissue samples. Results expressed as mean (SD)

\begin{tabular}{|c|c|c|c|c|c|c|}
\hline Patient number & Stage & Source & Leukaemic blast (\%) & Protein $(\mathrm{mg} / \mathrm{ml})$ & $\begin{array}{l}\text { Specific activity } \\
(U / m l)\end{array}$ & Units $/$ cell $\times 10^{7}$ \\
\hline Standard & & Peripheral blood & NA & 0.2 & 0.58 & 0.2 \\
\hline Normal $(n=10)$ & & Peripheral blood & NA & $0.81(0.28)$ & $0.69(0.45)$ & $0.13(0.09)$ \\
\hline Normal $(n=8)$ & & Bone marrow & NA & $1.19(0.76)$ & $0.7(0.59)$ & $0.13(0.1)$ \\
\hline ALL1 & Presentation & Peripheral blood & 86 & 1.24 & 0.93 & 0.24 \\
\hline ALL1 & Relapse & Peripheral blood & 93 & 0.52 & 1.92 & 0.2 \\
\hline ALL2 & Presentation & Peripheral blood & 82 & 1.2 & 1.08 & 0.25 \\
\hline ALL2 & Relapse & Peripheral blood & 96 & 1.13 & 0.9 & 0.2 \\
\hline ALL3 & Relapse & Peripheral blood & 93 & 1.01 & 1.26 & 0.26 \\
\hline ALL4 & Presentation & Peripheral blood & 89 & 0.92 & 1.13 & 0.24 \\
\hline ALL4 & Relapse & Peripheral blood & 68 & 1.13 & 1.26 & 0.3 \\
\hline ALL5 & Presentation & Peripheral blood & 35 & 1.44 & 0.78 & 0.22 \\
\hline ALL6 & Presentation & Peripheral blood & 98 & 1.18 & 1.05 & 0.25 \\
\hline ALL6 & Presentation & Bone marrow & 85 & 1.05 & 1.1 & 0.23 \\
\hline ALL7 & Presentation & Peripheral blood & 64 & 0.55 & 1.97 & 0.22 \\
\hline ALL7 & Presentation & Bone marrow & 95 & 0.87 & 1.23 & 0.21 \\
\hline ALL8 & Presentation & Peripheral blood & 76 & 0.52 & 2.45 & 0.26 \\
\hline ALL8 & Presentation & Bone marrow & 96 & 0.68 & 1.75 & 0.19 \\
\hline ALL9 & Presentation & Bone marrow & 96 & 0.82 & 1.18 & 0.19 \\
\hline
\end{tabular}

$\mathrm{NA}=$ not applicable.

(ALL1) between presentation and relapse when most of the protein measured can be accounted for by the leukaemic blast population. In one patient (ALL1) there is a noticeable increase in the specific activity $(\mathrm{U} / \mathrm{mg})$ of topoisomerase II measured between presentation and relapse whereas in a further two there is no significant change between presentation and relapse samples (ALL2 and 4). Only one patient (ALL3) shows a decrease in topoisomerase II specific activity. Differences in matched pairs of peripheral blood mononuclear cell and bone marrow mononuclear cell protein concentrations mirror changes in the percentage of leukaemic blasts in the sample. The specific activity for these

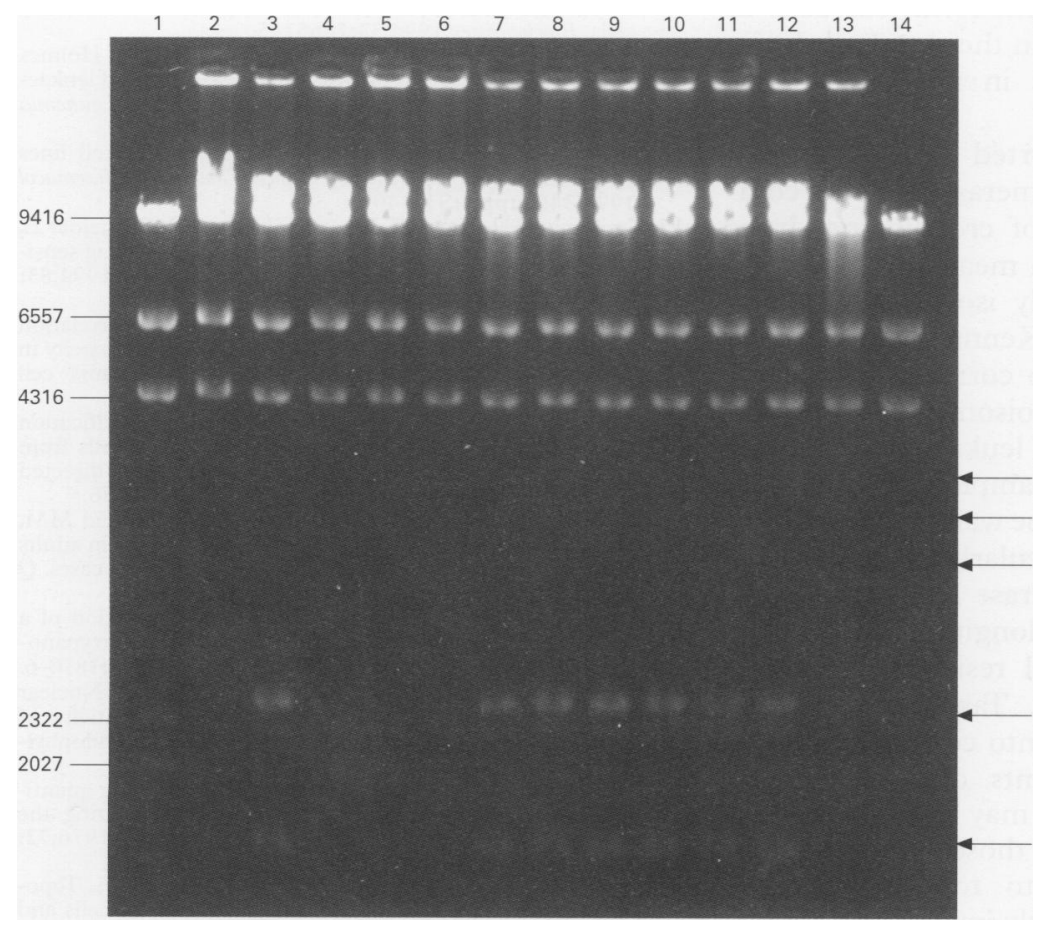

Figure 2 Electrophoresed agarose gel of kinetoplast fragments generated in the topoisomerase II assay, stained with ethidium bromide. Lanes 1 and 14 , Hind III cut $\lambda$ phage markers; lane 2, negative control; lane 3, CLL positive control; lane 4, ALL6 peripheral blood presentation; lane 5, ALL6 bone marrow presentation; lane 6, ALL7 peripheral blood presentation; lane 7, ALL7 bone marrow presentation; lane 8, ALL1 peripheral blood presentation; lane 9, ALL1 peripheral blood relapse; lane 10, ALL4 peripheral blood presentation; lane 11,ALL4 peripheral blood relapse. Left margin base pairs for markers, arrows: catenated Crithedia kinetoplast minicircles.

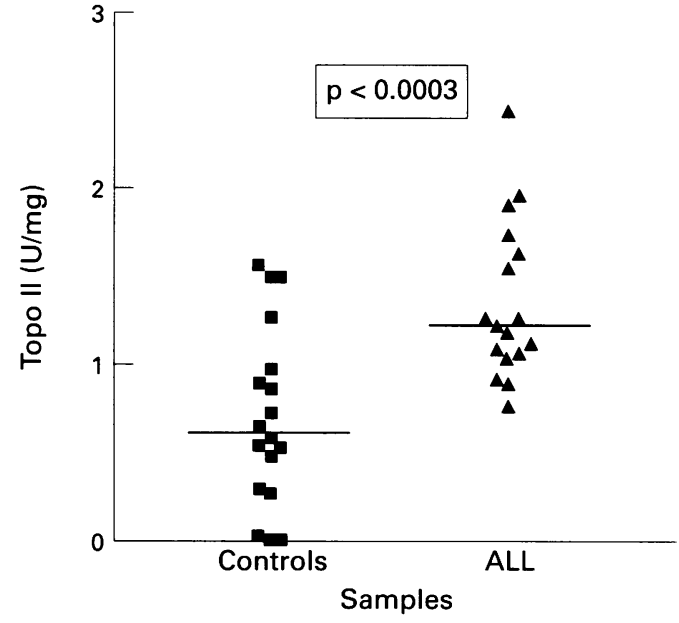

Figure 3 Scattergram of topoisomerase II activity of samples for normal and leukaemic cells, with the mean value for each group.

matched pairs shows lower levels of topoisomerase II activity found with increasing leukaemic blast percentages in the samples.

\section{Discussion}

The protozoan, Crithedia fasiculata, contains a mitochondrial genome of unusual structure. Most of the genetic information is contained on circular DNA molecules, maxicircles, which are linked together with a larger number of smaller minicircle DNA molecules, collectively known as the kinetoplast. Only topoisomerase II can successfully release (decatenate) and rejoin (catenate) minicirles from the kinetoplast.

Cells from a patient with CLL were chosen as the standard control as there was a reasonable quantity of topoisomerase II activity in the peripheral CLL cells and because of the nature of this disease, it was possible to obtain a single large donation of peripheral CLL cells to act as an internal standard. Aliquots of this internal standard lysate have been found to be stable for up to 12 months if stored in glycerol at $-80^{\circ} \mathrm{C}$. Other workers have reported that the activities of topoisomerase II are low in $\mathrm{CLL}^{24}$ and that this may be a reason 
why these patients become refractory to topoisomerase II inhibitory drugs. The CLL cells used as control in these experiments have higher topoisomerase II activities than a variety of haemopoietic cell lines (unpublished results) but similar to other samples from patients with CLL in our hands. These differences can be explained if there is translational control such that large amounts of active topoisomerase II are produced as has been reported for other proteins. Given the vast numbers of circulating cells in CLL, there would be a large reservoir of the topoisomerase II target for the cytotoxic drugs. It is interesting to note that the specific activity and activity per cell for the CLL control gave values approximating those seen in normal cells (table 3; fig 3).

The amount of enzymatically active topoisomerase II found in samples from patients with ALL is generally twice the level found in normal peripheral blood mononuclear cells or in bone marrow (mean (SD) $1.36(0.11)$ and $0.69(0.12)$, respectively). Normal peripheral blood mononuclear cells and bone marrow mononuclear cells give very similar activities of functional topoisomerase II and although there are different protein concentrations in the two cell populations, both peripheral blood mononuclear cells and bone marrow have similar specific activities and activites per cell (table 3; fig 3). Patient samples taken from bone marrow or blood gave comparable concentrations of active enzyme as long as the percentage blasts present were similar. Patient ALL5 had a lower number of leukaemic blasts in the presentation sample. The level of topoisomerase II activity in patient ALL5 is, therefore, an expression of the amount of topoisomerase II in the peripheral blood mononuclear cells in this sample and lies within the standard deviation seen in these cells in normal samples (table 3; fig3).

Ellis et $a l^{19}$ have reported a filter binding assay to measure topoisomerase II-DNA complexes in the presence of crosslinking drugs and hope to use this as a means of measuring drug sensitivity in freshly isolated leukaemic blast populations. McKenna et $a l^{15}$ have reported that there is no correlation between clinical outcome and topoisomerase II mRNA levels in acute myeloid leukaemia, although they state that as their sample size is small a multicentre study might be warranted. We have been unable to find particularly low concentrations of active topoisomerase II in CLL either at presentation or in longitudinal samples showing signs of clinical resistance to treatment (data not shown). Taking these comments and our findings into consideration, we believe that measurements of enzymatically active topoisomerase II may correlate better with clinical outcome in those diseases showing clinical resistance to topoisomerase II inhibitors. We are currently investigating active topoisomerase II concentrations in a panel of haemopoietic tumours to see whether these concentrations correlate with clinical progression.

The financial support of the Tyneside Leukaemia Research Fund is gratefully acknowledged.

1 Harrison DJ. Molecular mechanisms of drug resistance in tumours. F Pathol 1995;1 175:7-12.

2 List AF. Preclinical investigations of drug resistance [review]. Curr Opin Oncol 1995;7:19-27.

3 Patel S, Austin CA, Fisher LM. Development and properties of an etoposide-resistant human leukaemic ccrfcem cell line. Anti-Cancer Drug Design 1990;5:149-57.

4 Nitiss JL, Liu YX, Hsiung Y. A temperature sensitive topoisomerase II allele confers temperature dependent drug resistance on amsacrine and etoposide: a genetic system for determining the targets of topoisomerase II inhibitors. Cancer Res 1993;53:89-93.

5 Erickson LC. The role of O-6-methylguanine DNA methyltransferase (mgmt) in drug resistance and strategies for its inhibition [review]. Semin Cancer Biol 1991;2:257-65.

6 Hall AG, Cattan AR. Drug resistant mechanisms in leukaemia. In: Proctor SJ, ed. Minimal residual disease in leukaemia. London: Baillière, 1991:655-81.

7 Chen AY, Liu LF. DNA topoisomerases: Essential enzymes and lethal targets. Annu Rev Pharmacol Toxicol 1994;34: and lethal

8 Watt PM, Hickson ID. Structure and function of type II DNA topoisomerases. Biochem $\mathcal{7}$ 1994;303:681-95.

9 Drake FH, Zimmerman JP, McCabe FL, Bartus HF, Per SR, Sullivan DM, et al. Purification of topoisomerase II from amsacrine-resistant P388 leukemia cells. Evidence for two forms of the enzyme. F Biol Chem 1987;262:16739-47.

10 Harker WG, Slade DL, Parr RL, Feldhoff PW, Sullivan $\mathrm{DM}$, Holguin MH. Alterations in the topoisomerase II alpha gene, messenger RNA, and subcellular protein distribution as well as reduced expression of the DNA topoisomerase II beta enzyme in a mitoxantrone-resistant hl-60 human leukemia cell line. Cancer Res 1995;55:1707 16.

11 Wells NJ, Hickson ID. Human topoisomerase II $\alpha$ is phosphorylated in a cell-cycle phase-dependent manner by a proline-directed kinase. Eur F Biochem 1995;231:491-7.

12 Webb CD, Latham MD, Lock RB, Sullivan DM. Attenuated topoisomerase II content directly correlates with a low level of drug resistance in a Chinese hamster ovary cell line. Cancer Res 1991;51:6543-9.

13 Mestdagh N, Pommery N, Saucier J-M, Hecquet B, Fournier C, Slomianny C, et al. Chemoresistance to doxorubicin and cisplatin in a murine cell line. Analysis of P-glycoprotein, topoisomerase II activity, glutathione and P-glycoprotein, topoisomerase II activity, glutat

14 Burden DA, Sullivan DM. Phosphorylation of the $\alpha$ - and $\beta$-isoforms of DNA topoisomerase II is qualitatively different in interphase and mitosis in Chinese hamster ovary cells. Biochemistry 1994;33:14651-5.

15 McKenna SL, West RR, Whittaker JA, Padua RA, Holmes JA. Topoisomerase II $\alpha$ expression in acute myeloid leukaemia and its relationship to clinical outcome. Leukemia 1994;8:1498-502.

16 Doyle LA. Topoisomerase expression in cancer cell lines and clinical samples [review]. Cancer Chemother Pharmacol

17 Kauf;34(Supp1):S32-40. Zwellling LA, et al. Topoisomerase II levels and drug sensitivity in adult acute myelogenous leukemia. Blood 1994;83 517-30

18 Deffie AM, Batra JK, Goldenberg GJ. Direct correlation between DNA topoisomerase II activity and cytotoxicity in adriamycin-sensitive and -resistant P388 leukemia cell lines. Cancer Res 1989;49:58-62.

19 Ellis AL, Nowak B, Plunkett W, Zwelling LA. Quantification of topoisomerase-DNA complexes in leukemia cells from patients undergoing therapy with a topoisomerase-directed agent. Cancer Chemother Pharmacol 1994;34:249-56.

20 Proctor SJ, Taylor P, Thompson RB, Finney R, Reid MM, Hamilton PJ, et al. Acute lymphoblastic leukaemia in adults in the Northern Region of England-a study of 75 cases. $Q$ f Med 1985;57:761-74.

21 Melendy T, Ray DS. Novobiocin affinity purification of a mitochondrial type II topoisomerase from the trypanosomatid Crithidia fasciculata. $\mathcal{F}$ Biol Chem 1989;264:1870-6.

22 Davies SM, Robson CN, Davies SL, Hickson ID. Nuclear topoisomerase II levels correlate with the sensitivity of mammalian cells to intercalating agents and epipodophyllotoxins. F Biol Chem 1988;263:17724-9.

23 Bradford MM. A rapid and sensitive method for the quantitatiom of microgram quantities of protein utilizing the principle of protein-dye binding. Anal Biochem 1976;72: principle

24 McKenna SL, Whittaker JA, Padua RA, Holmes JA. Topoisomerase II expression in normal haemopoietic cells and chronic lymphocytic leukaemia: Drug sensitivity or resistchronic lymphocytic leukaemia: Drug sensitivity or resist-
ance. Leukemia 1993;7:1199-203. 